\title{
W SPRAWIE WYTWÓRCZOŚCI SZKLARSKIEJ W CELTYCKIM OPPIDUM W STARYM HRADISKU NA MORAWACH
}

\author{
ON GLASS PRODUCTION IN THE CELTIC OPPIDUM \\ AT STARÉ HRADISKO IN MORAVIA
}

\begin{abstract}
Jerzy Olczak
Instytut Archeologii, Uniwersytet Mikołaja Kopernika

ul. Szosa Bydgoska 44/48, 87-100 Toruń, Poland
\end{abstract}

\begin{abstract}
Discussion presented in the article is based upon analysis of glass fragments from the late La Tène oppidum. Existence of the jewellery manufacture workshop in Stare Hradisko, producing bracelets and possibly also beads of dark-blue, dark-yellow and green glass of external origin, is speculated based upon chemical composition of 5 fragments as well as morphological analysis. Further complex studies are postulated, which will facilitate unequivocal testing of the speculation about existence of glass works in Stare Hradisko. Analysed samples revealed presence of the soda-calcium-aluminium-silicon as well as the soda-calcium-lead-aluminium-silicon glass.
\end{abstract}

Celtycka wytwórczość szklarska i jej wyroby, głównie biżuteria, od dziesięcioleci są przedmiotem zainteresowania wielu europejskich badaczy - archeologów i technologów $^{1}$ - czego odzwierciedleniem są liczne publikacje obrazujące wysoki poziom tej dziedziny produkcji ${ }^{2}$.

$\mathrm{Na}$ obszarze środkowoeuropejskim szkło celtyckie reprezentowane jest przez stosunkowo bogate zespoły biżuterii, przede wszystkim przez bransolety i paciorki, a w niewielkim tylko stopniu przez naczynia ${ }^{3}$. Szczególną uwagę badacze poświęcają bransoletom, m.in. ze względu na ich różnorodność formalną, kolorystyczną oraz ornamentykę ${ }^{4}$ ulatwiającą ich porządkowanie typologiczne i chronologiczne ${ }^{5}$. Podjęto także interesującą próbę rekonstrukcji jednego ze sposobów (przy zastosowaniu tzw. rożna) formowania bransolet ${ }^{6}$.

\footnotetext{
'Hahn-Weinheimer 1956; Ankner 1965; Girdwoyń 1986.

${ }^{2}$ Zob. np. Filip 1956, s. 148-150; Haevernick 1960; Gebhard 1989; Venclová 1990.

${ }^{3}$ Venclová 1984.

${ }^{4}$ Lappe 1979; Meduna 1961; 1980; Karwowski 1997.

${ }^{5}$ Skutil 1939; Venclová 1980.

${ }^{6}$ Kunkel 1961.
} 
O ile wiedza o wyrobach celtyckiego szklarstwa, w tym także środkowoeuropejskiego, jest stosunkowo szeroka, o tyle stopień rozpoznania miejsc produkcji, zwłaszcza zaś pracowni z całym instrumentarium technicznym, w których wyroby te powstawały, nadal pozostaje niezadowalający i niewspółmierny do częstotliwości ich występowania w kulturze tego czasu ${ }^{7}$. Chcąc chociaż w niewielkiej części rozpoznanie to poszerzyć, uwagę naszą poświęcimy źródłom poświadczającym - naszym zdaniem - istnienie produkcji szklarskiej na wschodniej rubieży dotychczas znanych celtyckich ośrodków wytwórczych - na Morawach ${ }^{8}$.

W świetle znanych nam materiałów źródłowych jedynym takim miejscem na Morawach, w którym odkryto pozostałości po szklarskiej produkcji jest późnolateńskie oppidum (nazwa miejscowa Staré Hradisko) znajdujące się na gruntach miejscowości Malè Hradisko. Oppidum to jest rozległym, wyżynnym, trzyczęściowym obiektem zajmującym powierzchnię około 37 hektarów, o dość zwartej zabudowie, wśród której znajdują się także dwory; miało ono duże znaczenie w życiu społeczno-gospodarczym regionu.

W wyniku wieloletnich badań wykopaliskowych (z przerwami od 1925 r.) uzyskano tysiące różnorodnych przedmiotów oraz odkryto pozostałości urządzeń wytwórczych obrazujących wiele dziedzin produkcji - hutnictwo żelaza, kowalstwo, brązownictwo (m.in. wyrób fibul), garncarstwo (piece garncarskie), bursztyniarstwo, jubilerstwo, tkactwo, obróbkę skóry, drewna oraz mennictwo (formy do odlewania i tłoczenia złotych i srebrnych monet). Znaleziono ponadto liczne importy, także luksusowe, poświadczające rozległe kontakty handlowe miejscowych kupców".

Wśród tych znalezisk licznie reprezentowana jest szklana biżuteria w postaci bransolet, paciorków i odosobnionych pierścionków oraz pojedynczych fragmentów naczyń, być może celtyckich ${ }^{10}$. Bransolety, ulubiona ozdoba Celtów, charakteryzowały się dużą różnorodnością ornamentów, głównie plastycznych; wyróżniono aż 31 ich typów ${ }^{11}$.

Z punktu widzenia dopełnienia obrazu aktywności wytwórczej mieszkańców oppidum szczególną wartość poznawczą ma kilkadziesiąt amorficznych kawałków szkła (średnica 1-5 cm), pochodzących z rozbitych większych całości - brył będących bezpośrednim produktem wytopu. Ich barwa - ciemnoniebieska (kobaltowa), ciemnożółta (,miodowa”) i zielona - odpowiada barwom części biżuterii z oppidum.

${ }^{7}$ H a evernick 1974, s. 205.

${ }^{8}$ Pomijamy tu kwestię domniemanej produkcji szklarskiej na Kujawach (Przedbojewice), powstałej w okresie późnolateńskim rzekomo z inicjatywy celtyckiej (C o f t a - B r o n i e w s k a 1977; C of t a - B r on i ew s k a, K oś k o 1982, s. 187, 193; S t ol p i a k 1988, s. 235). Przesłanki źródłowe tej interesującej i oryginalnej hipotezy wymagają - naszym zdaniem - gruntownej reinterpretacji, a przede wszystkim bardziej szczegółowych opisów ich cech morfologicznych.

${ }^{9} \mathrm{M}$ e du na 1970a; 1970b; Pravéké dějiny 1993, s. 402-406, 415

${ }^{10}$ Materiały źródłowe do opracowania udostępnił autorowi dr J. Meduna - badacz Starego Hradiska w $1967 \mathrm{r}$.

${ }^{11}$ Skutil 1939. 
Celem uzyskania w miarę wiarygodnej odpowiedzi na pytanie o miejsce owych kawałków szkła w procesie produkcji szklarskiej, a co za tym idzie, ustalenie, czy są dowodem na istnienie miejscowej huty lub tylko pracowni (i o jakim profilu) ${ }^{12}$, losowo wybraliśmy pięć spośród nich (reprezentujących wszystkie trzy barwy) szczegółowo opisując ich cechy formalne i makroskopowo czytelne cechy technologiczne (por. Załącznik). Skład chemiczny tych szkieł określono za pomocą ilościowej analizy spektograficznej (tab. 1).

Wszystkie analizowane kawałki szkła łączą dwie takie same cechy: 1) każdy kawałek jest amorficzny, ma ostrokanciastą powierzchnię powstałą w wyniku celowego rozbicia większej całości na mniejsze części (ryc. 1,2) szkło jest niejednorodne, nie w pełni wyklarowane, gdyż zawiera liczne i bardzo liczne pęcherze gazowe, ponadto w dwóch kawałkach widoczne są smugi pasma niedobarwionego podczas wytopu szkła (Załącznik 1 i 4), a na powierzchni innego znajduje się dość gruba warstwa najprawdopodobniej nie stopionego zestawu surowcowego (Załącznik pkt 3, ryc. 1: 5).

Niewielkie rozmiary opisywanych kawałków szkła ograniczają pole obserwacji, co sprawia, że wnioskowanie o cechach ich pierwotnych całości może być obarczone nieokreślonym błędem. Niemniej jednak w świetle naszej wiedzy o starożytnym szklarstwie i regułach technologicznych z dużym prawdopodobieństwem można je łączyć z trzema fazami wytopu szkła.

1) Dwa kawałki (Załącznik pkt 2 i 5, ryc. 1: 3 i 4), mimo iż nie zostały w pełni wyklarowane (pęcherze gazowe), stanowią zakrzepłą ciemnoniebieską (kobaltową) szklaną masę $\mathrm{z}$ zakończonego procesu wytopu, która nadawala się do formowania $\mathrm{z}$ niej wyrobów.

2) Dwa kolejne kawałki (Załącznik pkt 1 i 4, ryc. 1 : 1 i 2) reprezentują szklaną masę ciemnożółtą i zieloną - zakrzepłą przed jej ujednorodnieniem; miejscami szkło jest wyraźnie nie dobarwione. Proces wytopu z nieznanych nam przyczyn w końcowej fazie został przerwany ${ }^{13}$. W tej postaci szkła te nie miały pelnych walorów techniczno-wyrobowych, przede wszystkim zaś estetycznych $\mathrm{i}$ - jak sądzimy - mogły nie nadawać się do formowania $\mathrm{z}$ nich wyrobów.

3) Ostatni kawałek (Załącznik pkt 3, ryc. 1: 5) to ciemnoniebieska (kobaltowa) niejednorodna szklana masa, zakrzepła przed całkowitym stopieniem zestawu surowcowego, którego warstwa znajduje się na jednej z jej powierzchni. W tej postaci szkło to również mogło nie nadawać się do formowania $z$ niego wyrobów ${ }^{14}$.

Niezależnie od faktu znalezienia tych podstawowych, wyjściowych prawie dla każdej pracowni szklarskiej materiałów w postaci zakrzepłej szklanej masy ${ }^{15}$, mamy do czynienia

${ }^{12}$ Dekówna 1988 , s. $16-18$.

${ }^{13}$ Szczegółowiej o tych kwestiach Dek ów na 1988; O lczak 1998.

${ }^{14} \mathrm{Tu}$ jednak pojawia się wątpliwość, czy naszą współczesną wrażliwość estetyczną można przykładać do ówczesnej, a zatem, czy zasadne jest twierdzenie o nieprzydatności tych szkieł do wyrobu biżuterii? Wątpliwość ta musi pozostać nie rozstrzygnięta.

${ }^{15}$ Istniały bowiem także pracownie, których produkcja opierała się na sprowadzanych z zewnątrz na przykład półfabrykatach (D e k ó w n a 1988, s. 6). 
z bardzo trudnym problemem ustalenia, co z niej w Starym Hradisku wytwarzano. Trudność jest tym większa, że dotychczas nie odkryto tu innych pozostałości produkcyjnych w postaci odpadów technicznych, powstających w czasie kształtowania różnych przedmiotów, nie odkryto też wyrobów nieudanych i półfabrykatów, które na ogół jednoznacznie pozwalają określić, co w badanym ośrodku produkowano ${ }^{\mathrm{lt}}$. Jedyną, lecz o pierwszorzędnym znaczeniu metodycznym, pomocną przesłanką jest przesłanka technologiczna. Otóż skład chemiczny szkła ciemnoniebieskiej bransolety barwionej tlenkiem kobaltu (CoO) i skład chemiczny kawałka ciemnoniebieskiego szkła także barwionego tlenkiem kobaltu są bardzo zbliżone (tab. 1: Skutil 1939 i 5/41: tab. 2: Skutil 1939 i 5/41). Mimo iż obie analizy wykonano różnymi metodami - klasyczną analizą chemiczną (tzw. mokrą; tab. 1: Skutil 1939) i ilościową analizą spektograficzną (tab. 1: 5/41) - to jednak wykryte procentowe zawartości głównych składników szkłotwórczych oraz ich sumy i proporcje, uwzględniając dopuszczalne granice tolerancji (dokładności) analitycznej ${ }^{17}$, odpowiednio wynoszą (tab. 2: Skutil 1939 i 5/41): $\mathrm{Na}_{2} \mathrm{O}+\mathrm{K}_{2} \mathrm{O}-19,3 \%$ i $19,9 \%, \mathrm{Na}_{2} \mathrm{O}: \mathrm{K}_{2} \mathrm{O}-20,6 \%$ i $21,1 \%, \mathrm{CaO}+\mathrm{MgO}-9,05 \%$ i $10,15 \%, \mathrm{CaO}: \mathrm{MgO}-$ $11,6 \%$ i $15,4 \%, \quad \mathrm{Na}_{2} \mathrm{O}+\mathrm{K}_{2} \mathrm{O}: \mathrm{CaO}+\mathrm{MgO}-2,1 \%$ i $1,3 \%, \mathrm{~K}_{2} \mathrm{O}: \mathrm{Na}_{2} \mathrm{O}+\mathrm{K}_{2} \mathrm{O} \times 100 \%$ 4,6\% i 4,5\%, MgO:CaO+MgO $\times 100 \%$ - 7,9\% i 6,4\%. Stosunkowo duża zbieżność składników alkalicznych i wapniowo-magnezowych występujących w obu szkłach barwionych identycznym barwnikiem (CoO) pozwala na sformułowanie wysoce prawdopodobnego wniosku, że na terenie oppidum w Starym Hradisku istniała pracownia, w której wyrabiano bransolety. Jaki był zakres ilościowy i jakościowy (inne jeszcze wyroby?) tej produkcji do czasu podjęcia dalszych badań nad problemem, głównie technologicznych, musi pozostać nie rozstrzygnięty. Nie można wszakże wykluczyć produkowania w tej pracowni także paciorków. Jednakże uzasadnioną wątpliwość budzi różnica w procentowej zawartości tlenku glinu $\left(\mathrm{Al}_{2} \mathrm{O}_{3}\right)$ w obu tych szkłach: w bransolecie wynosi ona 1,70\%, a w kawałku szkła 2,8\% (tab. 1: Skutil 1939, 5/41). Stosując bowiem przyjęte przez wielu badaczy kryteria określania typu chemicznego szkła, badane egzemplarze należałoby przyporządkować do dwóch różnych typów ${ }^{18}$ : bransoletę do typu sodowo-wapniowo-krzemowego $\left(\mathrm{Na}_{2} \mathrm{O} \cdot \mathrm{CaO} \cdot \mathrm{SiO}_{2}\right)$, a kawałek szkła do typu sodowo-wapniowo-glinowo-krzemowego $\left(\mathrm{Na}_{2} \mathrm{O} \cdot \mathrm{CaO} \cdot \mathrm{Al}_{2} \mathrm{O}_{3} \cdot \mathrm{SiO}_{2}\right)$. A zatem nie byłyby to szkła wytopione $\mathrm{z}$ tego samego zestawu surowcowego, co osłabiałoby nasz wniosek dotyczacy

${ }^{16}$ Zob. np. Henderson 1989, s. $44-46$.

${ }^{17}$ Olczak 1998, s. 59.

${ }^{18}$ Określenie typu chemicznego szkła opieramy na wcześniej wypracowanych kryteriach, na podstawie których szkła zawierające $\mathrm{w}$ swoim składzie mniej niż $1,3 \%$ tlenku potasowego $\left(\mathrm{K}_{2} \mathrm{O}\right)$ przy stosunku $\mathrm{Na}_{2} \mathrm{O}: \mathrm{K}_{2} \mathrm{O}$ równym lub większym od 13:1 zaliczane są do grupy sodowych, wytopionych przy użyciu sody pochodzenia mineralnego. Natomiast szkła, w których stężenie tlenku potasowego jest równe lub większe od $1,3 \%$ przy stosunku $\mathrm{Na}_{2} \mathrm{O}: \mathrm{K}_{2} \mathrm{O}$ mniejszym od 13:1, zalicza się do grupy szkieł wytopionych przy wykorzystaniu popiołów roślin bogatych w sód. Poza tym do nazwy typu chemicznego szkła wprowadza się składniki szkłotwórcze (obok tlenku sodowego), których stężenie wynosi: $\mathrm{K}_{2} \mathrm{O}-$ od $1,3 \%, \mathrm{CaO}-$ od $4,0 \%, \mathrm{PbO}-$ od $3,0 \%, \mathrm{MgO}-$ od 2,0\%, $\mathrm{Al}_{2} \mathrm{O}_{3}-$ od $2,0 \%$, ponadto zawsze $\mathrm{SiO}_{2}$. W omawianych tu szkłach pomija się inne składniki, niezależnie od ich koncentracji, np. $\mathrm{Fe}_{2} \mathrm{O}_{3}, \mathrm{MnO}$ (Deków na 1980, s. 31; S t a w i a r s k a 1984, s. 23,$24 ; 1987$, s. 38 ). 
miejscowej produkcji bransolet. Odwołując się jednak do wyżej wspomnianej tolerancji analitycznej w interpretacji wyników analiz składu chemicznego szkieł oraz faktu, iż wśród pięciu określonych laboratoryjnie składów chemicznych kawałków szkła nie występuje typ sodowo-wapniowo-krzemowy (tab. 1: 1/4-5/41), szkło omawianej bransolety najpewniej także należałoby zaliczyć do typu sodowo-wapniowo-glinowo-krzemowego (chociaż nie jest to przesłanka zbyt kategoryczna).

Tabela 1

Staré Hradisko, Morawy. Późnolateńskie oppidum celtyckie. Wyniki spektrografícznej analizy ilościowej składu chemicznego kawałków zakrzepłej masy szklanej (1/41-5/41) i wyniki analizy chemicznej (,klasycznej”) bransolety (Skutil 1939)*

Staré Hradisko, Mähren. Spätlatènezeitliches keltisches Oppidum. Ergebnisse der spektrographischen

Quantitätsanalyse chemischen Bestandteile in den Fragmente erstarrter Glasmasse (1/41-5/41) und Ergebnisse der chemischen („klassischen”) Analyse (Armrings - Skutil 1939)

\begin{tabular}{|c|c|c|c|c|c|c|}
\hline Nr analizy & $1 / 41$ & $2 / 41$ & $3 / 41$ & $4 / 41$ & $5 / 41$ & Skutil 1939 \\
\hline Barwa szkla & ciemnożólta & ciemnoniebiesk a & ciemnoniebieska & ciemnoniebieska & ciemnoniebieska & ciemnoniebieska \\
\hline \multicolumn{7}{|c|}{ Skladniki (w \% wagowych) } \\
\hline $\mathrm{SiO}_{2}$ & 71 & 68 & 68 & 62 & 64 & 67,24 \\
\hline $\mathrm{Na}_{2} \mathrm{O}$ & 14,2 & 15,2 & 14,8 & 16,4 & 19,0 & 18,15 \\
\hline $\mathrm{K}_{2} \mathrm{O}$ & 1,2 & 1,1 & 1,1 & 0,9 & 0,9 & 0,88 \\
\hline $\mathrm{CaO}$ & 5,0 & 9,0 & 9,5 & 7,9 & 9,5 & 8,33 \\
\hline $\mathrm{MgO}$ & ślady & 0,53 & 0,57 & 0,50 & 0,65 & 0,72 \\
\hline $\mathbf{A}]_{2} \mathrm{O}_{3}$ & 26 & 2,8 & 2,9 & 2,3 & 2,8 & 1,70 \\
\hline $\mathrm{Fe}_{2} \mathrm{O}_{3}$ & 0,60 & 0,93 & 0,83 & 0,50 & 1,3 & 1,42 \\
\hline $\mathrm{MnO}$ & ślady & 0,33 & 0,36 & 0,16 & ślady & - \\
\hline $\mathrm{Sb}_{2} \mathrm{O}_{3}$ & nie stwierdzono & nie stwierdzono & nie stwierdzono & $-0,25$ & nie stwierdzono & - \\
\hline $\mathrm{PbO}$ & $\sim 0,001$ & $\sim 0,001$ & ślady & $\sim 5$ & 0,021 & - \\
\hline $\mathrm{CoO}$ & nie stwierdzono & $>0,1$ & $>0,1$ & nie stwierdzono & $>0,1$ & 0,39 \\
\hline $\mathrm{CuO}$ & ślady & 0,32 & 0,24 & 2,2 & 0,25 & - \\
\hline $\mathrm{BaO}$ & $\sim 0,005$ & $-0,05$ & $-0,05$ & $-0,05$ & $-0,05$ & - \\
\hline $\mathrm{TiO}_{2}$ & 0,58 & 0,050 & 0,043 & 0,043 & 0,066 & - \\
\hline $\mathrm{SnO}_{2}$ & ślady & 0,037 & 0,040 & 0,10 & $\sim 0,001$ & - \\
\hline $\mathrm{B}_{2} \mathrm{O}_{3}$ & 0,005 & 0,31 & 0,33 & 0,10 & 0,34 & - \\
\hline $\mathrm{SrO}$ & nie stwierdzono & ślady & ślady & ślady & slady & - \\
\hline $\mathrm{V}_{2} \mathrm{O}_{5}$ & ślady & nie stwierdzono & nie stwierdzono & nie stwierdzono & nie stwierdzono & - \\
\hline $\mathrm{Cr}_{2} \mathrm{O}_{3}$ & $\sim 0,001$ & $\sim 0,001$ & $\sim 0,001$ & $\sim 0,0005$ & $\sim 0,001$ & - \\
\hline $\mathrm{NiO}$ & nie stwierdzono & $\sim 0,01$ & $\sim 0,01$ & nie stwierdzono & $\sim 0,01$ & - \\
\hline $\mathrm{ZnO}$ & nie stwierdzono & $\sim 0,1$ & $\sim 0,1$ & $\sim 0,1$ & $\sim 0,1$ & - \\
\hline $\mathrm{ZrO}_{2}$ & ślady & ślady & ślady & ślady & ślady & - \\
\hline $\mathrm{Ag}_{2} \mathrm{O}$ & $\sim 0,0005$ & $-0,0005$ & $-0,0005$ & $-0,001$ & $-0,0005$ & - \\
\hline $\mathrm{As}_{2} \mathrm{O}_{3}$ & nie stwierdzono & nie stwierdzono & nie stwierdzono & nie stwierdzono & nie stwierdzono & - \\
\hline Strata prażenia & 0,8 & 0,7 & 0,7 & 0,6 & 0,5 & - \\
\hline
\end{tabular}

* Analizy spektrograficzne wykonała mgr Anna Girdwoyń w laboratorium Instytutu Historii Kultury Materialnej (obecnie Instytut Archeologii i Etnologii) PAN w Warszawie. 
Tabela 2

Staré Hradisko, Morawy. Późnolateńskie oppidum celtyckie. Sumy i proporcje głównych składników szkłotwórczych w kawałkach zakrzepłej masy szklanej i bransolecie (Sk util 1939)

Staré Hradisko, Mähren. Spätlatènezeitliches keltisches Oppidum. Anteile und Proportionen der Hauptbestandteile in den Stücken erstarrter Glasmasse und eines Armrings (Skutil 1939)

\begin{tabular}{|c|c|c|c|c|c|c|c|}
\hline Nr ans & $\operatorname{lizv}$ & $1 / 41$ & $2 / 41$ & $3 / 41$ & $4 / 41$ & $5 / 41$ & Skutil 1939 \\
\hline \multicolumn{8}{|c|}{ Skladniki } \\
\hline \multicolumn{2}{|l|}{$\mathrm{Na}_{2} \mathrm{O}+\mathrm{K}_{2} \mathrm{O}$} & 15,4 & 16,3 & 15,9 & 17,3 & 19,9 & 19,3 \\
\hline \multicolumn{2}{|l|}{$\mathrm{Na}_{2} \mathrm{O}$} & \multicolumn{5}{|c|}{$\mathrm{K}_{2} \mathrm{O}$} & 20,6 \\
\hline \multicolumn{2}{|l|}{$\mathrm{CaO}+\mathrm{MgO}$} & 5 & 9,53 & 10,07 & 8,40 & 10,15 & 9,05 \\
\hline \multicolumn{2}{|l|}{$\mathrm{CaO}$} & 0 & 17,0 & 16,7 & 15,8 & 15,4 & 11,6 \\
\hline \multicolumn{2}{|l|}{$\mathrm{Na}_{2} \mathrm{O}+\mathrm{K}_{2} \mathrm{O}$} & 3,08 & 0,96 & 0,95 & 1,09 & 1,3 & 2,1 \\
\hline$\frac{\mathrm{K}_{2} \mathrm{O}}{\mathrm{Na}_{2} \mathrm{O}+\mathrm{K}_{2} \mathrm{O}}$ & $100 \%$ & 7,8 & 6,7 & 6,9 & 5,2 & 4,5 & 4,6 \\
\hline$\frac{\mathrm{MgO}}{\mathrm{CaO}+\mathrm{MgO}}$ & $100 \%$ & 0 & 5,6 & 5,7 & 5,9 & 6,4 & 7,9 \\
\hline \multicolumn{2}{|l|}{$\mathrm{Al}_{2} \mathrm{O}_{3}$} & $\geqslant 6$ & 2,8 & 2,9 & 2,3 & 2,8 & 1,70 \\
\hline
\end{tabular}

Z kolei wielowątkowy i wybitnie złożony jest problem pochodzenia odkrytych w Starym Hradisku kawałków szkła, w tym pięciu przebadanych laboratoryjnie. Ponieważ znaleziono je na złożu wtórnym ( $w$ warstwie kulturowej i na powierzchni tere$\mathrm{nu}$ ), a więc poza ich pierwotnym układem przestrzenno-funkcjonalnym, jedynie teoretycznie możemy wskazać na jedną z następujących, najbardziej prawdopodobnych możliwości. Mogły one pochodzić lub być rozwleczone: a) z huty, b) z pracowni ${ }^{19}$, c) z magazynu kupca. Rzeczywistość mogła także być zgoła inna, bardziej złożona. Gdyby jednak udało się wiarygodnie uzasadnić którąkolwiek z tych trzech możliwości, miałoby to daleko idące konsekwencje dla naszej wiedzy o szklarstwie celtyckim w ogóle.

A zatem, czy te kawałki szkła można uznać za dowód m i e j s c o w e go wytopu szkła i tym samym istnienia huty? Argumentem przemawiającym za jej istnieniem jest sam fakt odkrycia kawałków zakrzepłej masy szklanej, będącej bezpośrednim produktem wytopu. Po ich powtórnym roztopieniu w tyglu wstawionym do szklarskiego pieca ponownie

\footnotetext{
${ }^{19} \mathrm{O}$ formach organizacji produkcji szklarskiej: D e k ó w n a 1988 , s. 6-7, tam dalsza literatura: O l c z a k 1998, s. $16-18$.
} 
uzyskiwano płynną masę o odpowiedniej roboczej lepkości, z której można było formować różne wyroby. Przesłanką wzmacniającą pogląd o miejscowym pochodzeniu tych kawałków są trzy spośród nich, które „wypadły” (naszym zdaniem) z procesu wytopu przed jego zakończeniem. Nie są jednorodne i wyklarowane, a ich niskie walory estetyczne osłabiają możliwość wykorzystania ich w produkcji biżuterii (Załącznik 1, 3, 4) ${ }^{20}$. Jeśli zatem przyjmiemy, że szkła te nie miały cech technologiczno-estetycznych niezbędnych w produkcji m.in. biżuterii, to zarazem należy wątpić, czy takie szkła mogły być przedmiotem handlu i czy w takiej postaci były sprowadzane do oppidum. Stąd wypływa bardzo prawdopodobny wniosek, że są to odpady z nieudanego wytopu miejscowej huty. Ponieważ szkło najpewniej nie było ówcześnie tworzywem powszechnie dostępnym - mimo popularności szklanej biżuterii - należałoby przyjąć, że nieudane kawałki ponownie przetapiano, aby uzyskać pełnowartościowy produkt.

Zarazem jednak nie można nie brać pod uwagę przeciwstawnych argumentów o podobnej sile dowodowej przeciwko koncepcji mówiącej o działaniu w Starym Hradisku huty szkła. Otóż, mimo wieloletnich badań wykopaliskowych obejmujących znaczną powierzchnię oppidum, nie natrafiono nie tylko na urządzenia wytwórcze in situ (pozostałości, ruiny pieców szklarskich), lecz także chociażby w rozproszeniu, na ich pojedyncze elementy konstrukcyjne, fragmenty tygli (donic), ułamki żelaznych narzędzi hutniczych, a przede wszystkim na tzw. łezki (sople) - próbki szkła, które hutnik wielokrotnie pobierał z tygla lub pieca wannowego w celu sprawdzenia, czy topiona masa jest już jednorodna, czy ma właściwą barwę i stopień przezroczystości oraz odpowiednią roboczą (wyrobowa) lepkość.

Ponieważ $w$ innych oppidach celtyckich dotychczas także nie znaleziono nie budzących wątpliwości dowodów (np. tygli, pieców) na miejscowy wytop szkła z zestawu surowcowego, niektórzy badacze sądzą, że Celtowie nie opanowali technologii wytopu i szkło w postaci półproduktu (półfabrykatu) - bloków, bryl, sztab - sprowadzali z szeroko rozumianego Południa (,na południe od Alp”), aby na miejscu produkować z niego głównie biżuterię $e^{21}$.

Warto tu przypomnieć, że wątpliwości co do trafnego określenia pochodzenia/przeznaczenia niektórych szklarskich znalezisk zdarzały się niejednokrotnie ${ }^{22}$. Odkrywane pozostalości poprodukcyjne bądź półfabrykaty, bądź szkło nie przetworzone, z powodu nieczytelnych kontekstów przestrzenno-użytkowych lub ich braku nie mogły być wiarygodnie przyporządkowane do żadnej formy szklarskiej działalności produkcyjnej lub organizacyjnej. Nie było bowiem wiadomo, czy należało je wiązać z miejscową hutą (wytop szkła), z określonym rodzajem pracowni (formowaniem wyrobów - jakich?), czy wreszcic - $z$ handlem.

Uwzględniając przytoczone wyżej bezpośrednie i pośrednie przesłanki, hipotezę o istnieniu w Starym Hradisku huty szkła ( = wytop szklanej masy) należy odrzucić. W tej

\footnotetext{
${ }^{20}$ Por. jednak przyp. 14

${ }^{21}$ Haevernick 1974, s. 205-208; Henderson 1989, s. 44-47; Venclová 1990, s. 145, zob. też mapę 9.

${ }^{22}$ Np. L'v ova, N a u mov 1970, s. $185,186$.
} 
sytuacji za najbardziej prawdopodobną należy uznać następującą interpretację znalezionych tu kawałków szkła: w oppidum dzialała pracownia przetwórcza, w której produkowano szklaną biżuterię (bransolety i zapewne paciorki) ze szkła w postaci sztab? bloków? placków? dostarczanych z zewnątrz z huty/hut o nieznanej nam lokalizacji ${ }^{2.3}$. Sztaby? bloki? placki? rozdrabniano (rozbijano) na miejscu w pracowni i przetapiano w tyglach (donicach) umieszczanych w odpowiednim piecu roboczym.

Zarazem jesteśmy przekonani, że na obecnym etapie rozpoznania całokształtu celtyckiego szklarstwa możliwość zweryfikowania proponowanej przez nas interpretacji jest stosunkowo niewielka. Wymagałoby to bowiem podjęcia szczegółowych i szerokich badań porównawczych, przede wszystkim na podstawie wyników licznej serii analiz składu chemicznego celtyckich szkiel, zwlaszcza nie przetworzonego szkła i biżuterii z oppidów, w pierwszym etapie położonych na terenie Moraw, Słowacji, Czech, Austrii, Niemiec i Szwajcarii. Niezbędnym warunkiem takich badań byłoby wykonanie tych analiz jedną i tą samą metodą w jednym laboratorium, co jednak ze względów organizacyjnych w najbliższym czasie nie wydaje się możliwe. Równocześnie nie można nie podkreślić, że byłby to dobry punkt wyjścia do dalszych dociekań zmierzających do rozstrzygnięcia podstawowej kwestii szklarstwa celtyckiego, jaką jest zlokalizowanie huty/hut, w których wytapiano szkło następnie rozprowadzane/sprzedawane do pracowni przetwórczych znajdujących się w różnych oppidach.

Trzecia sformułowana przez nas hipoteza, zakładająca, że znalezione w Starym Hradisku kawałki szkła mogły pochodzić z magazynu kupca, nie ma rzeczowego uzasadnienia. Teoretycznie wszakże jest nader prawdopodobna. Sprowadzane bowiem z zewnątrz nie przetworzone szkło, najpewniej właśnie przez kupca, zanim zostało wykorzystane w pracowni przetwórczej kupiec ów składował w swoim magazynie. W różnych okolicznościach „towar” ten mógł być rozwleczony poza magazyn i znalazł się na złożu wtórnym.

Zakres charakterystyki technologicznej szkieł ze Starego Hradiska warunkuje limitowana objętość naszego artykułu. $Z$ konieczności więc przedstawiamy ją (charakterystykę) jedynie opisowo, pogłębioną zaś analizę, także w szerszych kontekstach porównawczych odkładając do dalszych studiów, które być może podejmą również inni badacze. Przy czym w studiach porównawczych nie należy tracić z pola widzenia bardzo istotnych ograniczeń poznawczych, wynikających $z$ faktu wykonywania analiz składu chemicznego szkieł celtyckich w różnych europejskich laboratoriach, często nieporównywalnymi metodami analitycznymi. Wyniki takich analiz dla szczegółowych, porównawezych dociekań technologicznych mogą się okazać mało przydatne.

\footnotetext{
${ }^{23}$ Handel tego rodzaju nie przetworzonym szkłem (surowcem szklanym) w dziejach szklarskiej wytwórczości nie był zjawiskiem odosobnionym (np. L i e r k e 1999, s. 8-11), podobnie jak zróżnicowane pod względem zakresu produkcji huty/pracownie (np. F o y 2000, s. 147-170; N e n n a, P i c o n, V i c h y 2000, s. 97-112).
} 
Mimo iż seria analiz składu chemicznego kawałków szkła (zakrzepłej szklanej masy) ze Starego Hradiska jest nieliczna, zaś z punktu widzenia oceny statystycznej wręcz śladowa, to jednak pozwala na pewne interesujące obserwacje. Otóż aż cztery spośród analizowanych szkieł należą do sodowych typu sodowo-wapniowo-glinowo-krze-

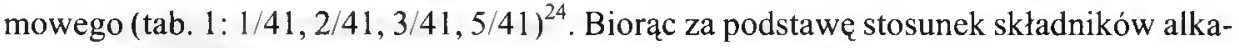
licznych do składników ziem alkalicznych $\mathrm{Na}_{2} \mathrm{O}+\mathrm{K}_{2} \mathrm{O}: \mathrm{CaO}+\mathrm{MgO}$; (tab. 2, 1/41, 2/41, $3 / 41,5 / 41$ ) występujących w tych szkłach, można je przyporządkować do grupy szkieł, które wytapiano z trzyskładnikowego zestawu surowcowego: sody mineralnej + piasku + surowców wapniowych. Tak jest wówczas, gdy stosunek ten jest równy lub mniejszy od cyfry $3^{25}$. W jednym tylko przypadku wartość ta jest większa o 0,8 (tab. 2: 1/41), najpewniej spowodowana nieco innym i w nieco innych proporcjach użytym do wytopu tego szkła surowcem wapniowym ( $\mathrm{CaO}-5,0 \%, \mathrm{MgO}$ - ślady: tab. 1: 1/41). Wskazywałaby na to także wyższa niż w pozostałych szkłach koncentracja tlenku glinowego $\left(\mathrm{Al}_{2} \mathrm{O}_{3}-\leqslant 6 \%\right)$ oraz brak niektórych pierwiastków śladowych (np. SrO, $\left.\mathrm{NiO}, \mathrm{ZnO}\right)$. Byłby to zatem jeden z dowodów na dostarczenie do pracowni w Starym Hradisku szkła wytapianego z częściowo różnych ,wsadów" surowcowych, również różnie barwionych. Trzy bowiem barwione były tlenkiem kobaltu ( $\mathrm{CoO}->0,1 \%)$ na ciemnoniebiesko i jeden tlenkiem miedziowym ( $\mathrm{CuO}-2,2 \%$ ) na zielono, jeden zaś związkami żelaza na ciemnożółto. Z kolei występujący we wszystkich analizowanych szkłach tlenek glinowy wprowadzony został do zestawu surowcowego wraz z piaskiem jako jego naturalna domieszka ${ }^{26}$.

Kolejnym dowodem na dostarczenie do pracowni w Starym Hradisku surowego szkła wytapianego z różnych zestawów surowców jest szkło zakwalifikowane przez nas do typu sodowo-wapniowo-ołowiowo-glinowo-krzemowego (tab. 1: 4/41). Jego skład chemiczny odbiegający od pozostałych wymaga krótkiego komentarza.

Poza stosunkowo niewielkimi różnicami w koncentracji podstawowych składników szkłotwórczych, uwagę zwraca przede wszystkim obecność tlenku ołowiawego (PbO około $5 \%$ ), tlenku antymonawego $\left(\mathrm{Sb}_{2} \mathrm{O}_{3}\right.$ - około $\left.0,25 \%\right)$, których nie stwierdzono w pozostałych szkłach, oraz tlenku cynowego $\left(\mathrm{Sn}_{2} \mathrm{O}-0,10 \%\right)$, a także tlenku miedziowego ( $\mathrm{CuO}-2,2 \%)$ wprowadzonego do zestawu jako barwnik. Ten nietypowy układ składników surowcowych jest dość trudny do jednoznacznej oceny. Biorąc wszakże pod uwagę zbliżone wartości procentowe głównych składników szkłotwórczych $\left(\mathrm{SiO}_{2}\right.$, $\mathrm{Na}_{2} \mathrm{O}, \mathrm{CaO}, \mathrm{Al}_{2} \mathrm{O}_{3}$ ) we wszystkich pięciu analizowanych szkłach, omawiany typ można by interpretować jako odmianę (podtyp?) typu sodowo-wapniowo-glinowo-krzemowego. Najprawdopodobniej powstał on w wyniku celowego zabiegu hutniczego, polegającego na wprowadzeniu surowca ołowiowego do topionego, ,tradycyjnego" zestawu sodowo-wapniowo-glinowo-krzemowego. Jednakże nie potrafimy określić i objaśnić

\footnotetext{
${ }^{24}$ Por. przyp. 18

${ }^{25}$ Š č a pova 1977, s. $98-104 ; 1983$, s. $45-46$. Ale por. inny pogląd w tej sprawie sformulowany przez M. Dekównę $(1996$, s. 23, 30).

${ }^{26}$ Ten składnik szkieł starożytnych dość powszechnie tak właśnie jest interpretowany (B e z b o r odov 1969, tab. 10-13).
} 
przesłanek technologicznych i użytkowych, które mogłyby uzasadnić wytop takiej szklanej masy. Jedynie jako daleko idący domysł - trudny zresztą do zweryfikowania - można by przyjąć, że hutnik chcąc wytopić nieprzezroczyste szkło (zamówione przez kupca lub wytwórcę biżuterii) wykorzystał do tego celu ołów zawierający naturalne domieszki cyny i antymonu, które mąciły topioną masę (antymon w odpowiednim stężeniu $)^{27}$.

Wyjątkowość omawianego egzemplarza szkła potwierdzają także wyniki analiz kilkuset szkieł starożytnych typu sodowo-wapniowo-glinowo-krzemowego z różnych rejonów Europy i Bliskiego Wschodu, w których składzie nie wykryto znaczących koncentracji (na ogól dużo poniżej jednego procenta) tlenku ołowiawego $(\mathrm{PbO})^{28}$. Jako ,przypadek odosobniony" traktuje M. Dekówna takie szkło $\left(\mathrm{Na}_{2} \mathrm{O} \cdot \mathrm{CaO} \cdot \mathrm{Al}_{2} \mathrm{O}_{3} \cdot \mathrm{PbO}\right.$ [?] $\left.\mathrm{SiO}_{2}\right)$, stwierdzone w przezroczystym, ciemnozielonym paciorku, datowanym na III lub IV w. n.e., odkrytym w obozie legionowym w Caerleon (Walia) ${ }^{29}$. Przy czym tlenek ołowiawy stanowił w nim aż $9,12 \%$.

Podsumowując nasze dociekania i formułowane mniej lub bardziej zasadne hipotezy, dla których podstawą są wyniki analizy składu chemicznego pięciu kawałków szkła oraz sumy i proporcje występujących w nich głównych składników szkłotwórczych ${ }^{30}$, można wysnuć jedynie następujące robocze wnioski:

1. W oppidum w Starym Hradisku w okresie późnolateńskim działała pracownia przetwórcza, w której wytwarzano szklane bransolety i prawdopodobnie paciorki.

2. Surowe szkło do ich produkcji sprowadzano z zewnątrz, z nieokreślonej huty/hut, która/które zapewne korzystały z jednego źródła (złoża) szklarskiego piasku, o czym przekonuje uderzająco zbliżone stężenie wykrytego w nich tlenku glinowego $\left(\mathrm{Al}_{2} \mathrm{O}_{3}\right.$; tab. 1: 2/41-5/41). Jedynie w kawałku szkła ciemnożółtego stężenie to jest znacznie zawyżone (tab. 1:1/41).

3. Hutnicy, którzy wytapiali szkło dostarczane do Starego Hradiska, najprawdopodobniej znali tylko jedna, podstawową technologię sodowo-wapniowo-glinowo-krzemową wykorzystując trzy rodzaje surowców: sodę krystaliczną, wapień i piasek zawierający naturalną domieszkę glinu.

4. Do barwienia szklanej masy na ciemnoniebiesko wykorzystywali kobalt $(\mathrm{CoO})$, na zielono miedź $(\mathrm{CuO})$, a na ciemnożółto związki żelaza $\left(\mathrm{Fe}_{2} \mathrm{O}_{3}\right)$. Dla uzyskania szkła nieprzezroczystego stosowali ołów (PbO) stanowiący dla naszej klasyfikacji

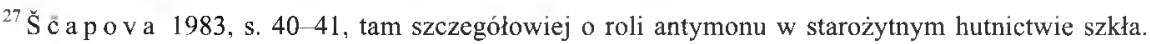

${ }^{28}$ B ezborodov 1969, tab. V; Stawiarska 1999, Aneks 1 i 3.

${ }^{29}$ Dekówna 1980, s. $76-83$, tab. 10.

${ }^{30}$ Nadal podtrzymujemy nasz wcześniej wyrażony pogląd o konieczności krytycznego traktowania wyników analiz laboratoryjnych - mimo ich ciagłego doskonalenia - szkicł wykopaliskowych, które od wielu już lat niewatpliwie stanowia jedno z podstawowych źródeł informacji o dzicjach wytwórczości szklarskiej (Olczak 1998, s. 59 i przyp. 23).
} 


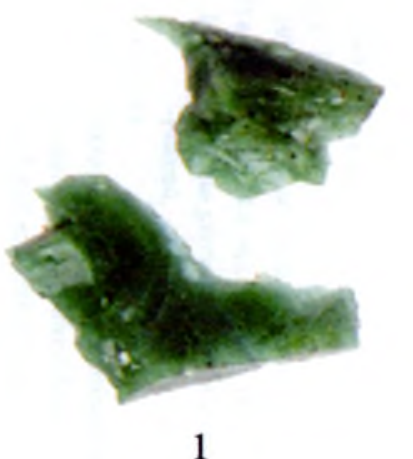

1

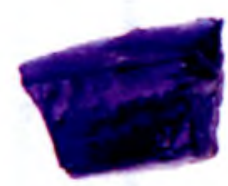

3

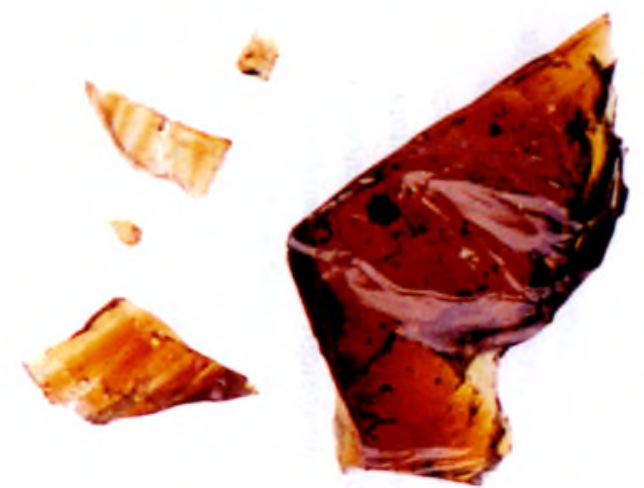

2
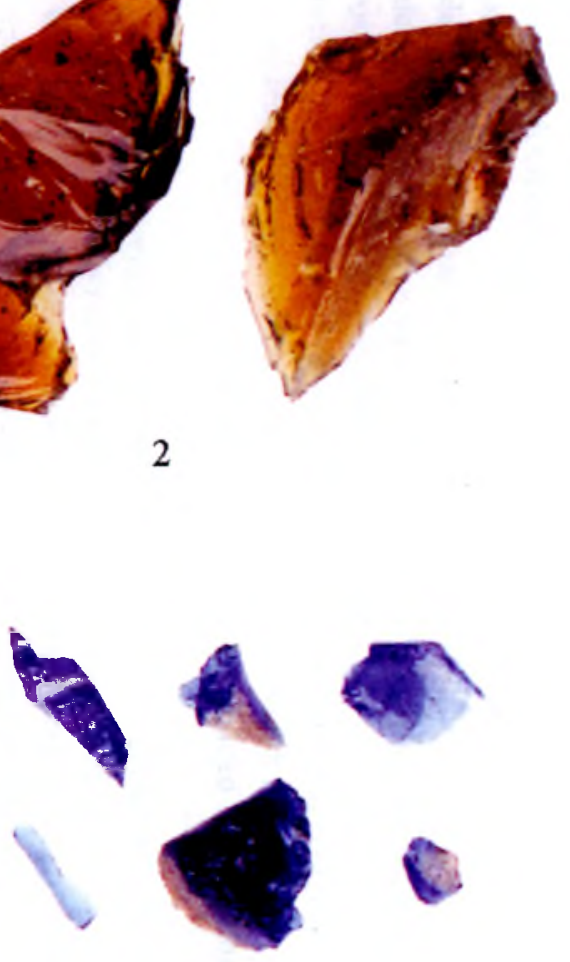

5

Staré Hradisko, Morawy. Oppidum celtyckie. Kawalki zakrzepłej szklanej masy (por. Załącznik pkt 1-5). Fot. A. Janowski Staré Hradisko, Mähren. Keltisches Oppidum. Fragmente von der erstarrten Glasmasse (vgl. Anhang, Nr. 1-5). Phot. A. Janowski 
technologicznej podstawę wyróżnienia szkła odmiany sodowo-wapniowo-ołowiowo-glinowo-krzemowej.

Wnioski te - naszym zdaniem - są dobrą podstawą do dalszych pogłębionych badań, także technologicznych, oraz otwierają możliwość bardziej kompleksowych i porównawczych dociekań nad problemem celtyckiej wytwórczości szklarskiej w Starym Hradisku.

Zadaniem takich badań przede wszystkim powinno być:

1) umiejscowienie ośrodka bądź regionu, w którym znajdowała się huta (huty), skąd sprowadzano do Starego Hradiska surowe szkło,

2) określenie pełnego asortymentu produkcji miejscowej pracowni przetwórczej - tzn. jakie rodzaje biżuterii w niej wytwarzano i czy również naczynia,

3) ponowne podjęcie próby jednoznacznego i wiarygodnego rozstrzygnięcia kwestii miejscowego wytopu szkła.

Aby zadania te wykonać, należałoby - jako warunek niezbędny - przeprowadzić:

a) szczegółową, analityczną kwerendę w zbiorach z badań wykopaliskowych prowadzonych na terenie oppidum, i to nie tylko szklarskich, ale także metali i ceramiki, w celu odnalezienia ewentualnych fragmentów żelaznych narzędzi szklarskich, donic (tygli) i elementów konstrukcyjnych urządzeń wytwórczych,

b) wykonanie kilkudziesięciu (co najmniej) analiz składu chemicznego kolejnych kawałków szkła i reprezentacji wszystkich kategorii przedmiotów szklanych znalezionych w Starym Hradisku.

Realizacja tych zamierzeń mogłaby rzutować również na całościowy wizerunek szklarstwa w środkowowschodnim rejonie świata celtyckiego.

\section{BIBLIOGRAFIA}

\section{Ankner D}

1965 Chemische und physikalische Untersuchungen an vor- und frühgeschichtlichen Gläser, cz. I, (w:) Technische Beiträge zur Archäologie II, Mainz, s. 74-101.

Bezborodov M.A.

1969 Chimija i technologija drevnich i srednevekovych stekol, Minsk.

Cofta-Broniewska A.

1977 Celtowie, szkło, Kujawy - sensacja 1976, ,Z otchłani wieków” R. 43, nr 1, s. 12, 13.

Cofta-Broniewska A., Kośko A.

1982 Historia pierwotna spoteczeństw Kujaw [Sum.: Prahistory of Cuiavian Societies], Warszawa-Poznań

Dekówna $\mathrm{M}$

1980 Szklo w Europie wczesnośredniowiecznej [Sum.: Glass in Early Medieval Europe], Wrocław.

1988 Uwagi na temat klasyfikacji i interpretacji pozostatości starożytnej $i$ wczesnośredniowiecznej produkcji szklarskiej [Sum.: Remarks to the Classification and Interpretation of the Ancient and Early Mediaeval Glass-Making Relics], (w:) Studia nad etnogeneza Stowian i kulturq Europy wczesnośredniowiecznej, t. 2, red. G. Labuda, S. Tabaczyński, Wrocław, s. 5-20.

1996 Szklo okienne z fortu rzymskiego w Gelligaer w poludniowej Walii [Rès.: Le verre à vitre du fort romain à Gelligaer dans le sud du pays de Galles], „Acta Universitatis Nicolai Copernici, Archeologia" t. 26, s. 7-68. 
Filip J.

1956 Keltové ve středni Evropé, Monumenta Archaeologica, t. 5, Praha.

Foy D.

2000 Technologie, géographie, économie: les ateliers de verriers primaires et secondaires en Occident. Esquisse d'une évolution de l'Antiquité au Moyen Age, (w:) La route du verre. Ateliers primaires et secondaires du second millénaire av. J.-C. au Moyen Age, red. M.-D. Nenna, Lyon, s. $147-170$.

Gebhard R.

1989 Der Glasschmuck aus dem Oppidum von Manching, Die Ausgrabungen in Manching, t. 11. Girdwoyń A.

1986 Celtic glass bracelets from excavations in Poland. A technological study, „Archaeologia Polona” t. $25 / 26$, s. $199-208$.

Haevernick Th.E.

1960 Die Glasarmringe und Ringperlen der Mittel- und Spätlatènezeit auf dem europäischen Festland, Bonn.

1974 Gedanken zur frühesten Glasherstellung in Europa, ,Jahrbuch des Römisch-Germanischen Zentralmuseums Mainz" R. 21, s. 205-209.

Hahn-Weiheimer P.

1956 Spektrochemische und physikalische Untersuchungen an latènezeitlichen Glasfunden aus dem Oppidum von Manching (1955), Beilage zum Sammelblatt des Historischen Vereins Ingolstadt, Ingolstadt

Henderson $\mathrm{J}$.

1989 The scientific analysis of ancient glass and its archaeological interpretation, (w:) Scientific analysis in archaeology and its interpretation, ed. J. Henderson, Oxford, s. 30-62.

Karwowski M.

1997 Keltische Glasfunde im polnischen Gebiet, „Przegląd Archeologiczny” t. 45, s. 33-71.

Kunkel O.

1961 Zur Frage keltischer Glasindustrie, „Germania” R. 39, z. 3/4, s. 322-329.

Lappe U.

1979 Keltische Glasarmringe und Ringperlen aus Thüringen, „Alt-Thüringen” t. 16, s. 84-111.

Lierke R.

1999 Antike Glastöpferei. Ein vergessenes Kapitel der Glasgeschichte, Mainz am Rhein.

L'vova Z., Naumov D.

$1970 K$ voprosu o proischoždenii stekljannych bus VIII-Xvv. Staroj Ladogi, „Slavia Antiqua” t. 17, s. $179-186$.

Meduna J.

1961 Staré Hradisko. Katalog nálezů uložených v muzeu města Boskovic, Fontes Archaeologici Moravicae, t. 2, Brno.

1970a Staré Hradisko II, Fontes Archaeologiae Moravicae, t. 5, Brno.

1970b Das keltische Oppidum Staré Hradisko in Mähren, „Germania” 48, Nr 1-2, s. 34-59.

1980 Die latènezeitlichen Siedlungen in Mähren, Prag.

Nenna M.-D., Picon M., Vichy M.

2000 Ateliers primaires et secondaires en Égypte à l'époque gréco-romaine, (w;) La route du verre. Ateliers primaires et secondaires du second millénaire av. J.-C. au Moyen Age, ed. M.-D. Nenna, Lyon, s. 97-112.

Nowotny W.

1969 Szkła barwne, Warszawa.

Olczak J.

1998 Produkcja szkła w rzymskim i wczesnobiznatyjskim Novae w świetle źródel archeologicznych (Mezja Dolna) [Sum.: Glass Production in Roman and Early Byzantine Novae in the Light of Archaeological Sources (Moesia Inferior)], Toruń. 


\section{Pravěké déjiny}

1993 Pravěké dějiny Morawy. Vlastivĕda moravská země a lid, red. V. Podborský, Brno.

Skutil J.

1939 Sklenēné náramky ze Starého Hradiska, „Ročenka musea v Prostějově” R. 16, s. 110-119. Stawiarska T.

1984 Szkla z okresu wptywów rzymskich z pótnocnej Polski. Studium technologiczne [Sum.: Glasses from Roman Period Excavated in Northern Poland. A Chemical Assays], Wrocław.

1987 Metody porównań skladów chemicznych szkiel zabytkowych ze szczególnym uwzglednieniem okresu wplywów rzymskich [Sum.: Methods of Interpretation of Chemical Composition of Ancient Glass with Particular Reference to the Period of Roman Influence], ,Acta Universitatis Nicolai Copernici, Archacologia" t. 12, s. 35-49.

1999 Naczynia szklane okresu rzymskiego z terenu Polski. Studium archeologiczno-technologiczne [Sum.: Roman-Period Vessels in Poland. Archacology and Technology], Warszawa

Stolpiak B.

1988 Szklo w kulturze spoleczeństw przeworskich Kujaw - aspekt technologiczny, (w:) Kontakty pradziejowych spoleczeństw Kujaw z innymi ludami Europy. Studia i materialy do dziejów Kujaw, t. 2, red. A Cofta-Broniewska, Inowrocław, s. 229 265.

\section{Šč a pova J.L}

1977 O chimičeskom sostave drevnego stekla, ,Sovetskaja Archeologija” nr 3, s. 95-106.

1983 Očerki istorii drevnego steklodelija (po materialam dolina Nila, Bliżnego Vostoka i Evropy), Moskva.

Venclová $\mathrm{N}$.

1980 Nástin chronologie laténských skleněných náramků v Cechách, „Památky archeologické” t. 71, z. 1, s. 61-92.

1984 On the problem of Celtic glass vessels, „Památký archeologické” t. 75, s. 445-457.

1990 Prehistoric glass in Bohemia, Praha.

\section{ZALĄCZNIK}

\section{STARE HRADISKO (nazwa miejscowa)}

Malé Hradisko, okr. Prostějov, Morawy.

Późnolateńskie oppidum celtyckie.

Badania: Wykopaliskowe w 1965 r.; dr Jiří Meduna, Archeologický ústav CSAV Brno.

Opis analizowanych laboratoryjnie kawałków zakrzepłej masy szklanej.

1. Nieregularny, amorficzny kawałek zakrzepłej, niejednorodnej, przezroczystej i błyszczącej masy szklanej, o intensywnie ciemnożółtej (miodowej, bursztynowej) barwie, którą najprawdopodobniej spowodowały obecne w szkle związki żelaza $\left(\mathrm{Fe}_{2} \mathrm{O}_{3}-\right.$ $0,60 \%)$ i dwutlenek tytanu $\left(\mathrm{TiO}_{2}-0,58 \%\right)$ (por. Nowotny 1969 , s. 115-116). Miejscami widoczne są równoległe, różnej grubości warstwy szkła o różnych odcieniach - od żółtomiodowej do jasnobrunatnej - w tym także bezbarwne. Szklo zawiera liczne, różnej wielkości, okrągłe (większość) i soczewkowate pęcherze gazowe, układające się równolegle w stosunku do niejednorodnych warstw szkła. Masa ta nie została w pełni wyklarowana (smugi, pęcherze gazowe), zakrzepła - w nieokreślonych okolicznościach - przed zakończeniem procesu wytopu. 
Stan zachowania szkła: bardzo dobry.

Wymiary: 3,5 ×3,8 ×4,1 cm (do analizy odłupano sześć drobnych kawałków szkła).

Lokalizacja: znalezisko luźne, z powierzchni oppidum; inw. č. 602-4/65; ryc. 1: 2.

Typ chemiczny szkła: sodowo-wapniowo-glinowo-krzemowe $\left(\mathrm{Na}_{2} \mathrm{O} \cdot \mathrm{CaO} \cdot \mathrm{Al}_{2} \mathrm{O}_{3} \cdot \mathrm{SiO}_{2}\right.$; tab. 1: $1 / 41$; tab. $2: 1 / 41$ ).

2. Nieregularny, amorficzny kawałek zakrzepłej, jednorodnej, przejrzystej i błyszczącej ciemnoniebieskiej (granatowej) masy szklanej, barwionej tlenkiem kobaltu (CoO - >0,1\%). W szkle widoczne są bardzo liczne okraggłe, na ogół małe pęcherze gazowe bez czytelnego układu. Masa nie została całkowicie wyklarowana (pęcherze gazowe). Powierzchnia szkła miejscami zastygła, miejscami nosi ślady odbicia.

Stan zachowania szkła: bardzo dobry.

Wymiary: $0,6 \times 0,8 \times 1,0 \mathrm{~cm}$ (do analizy odłupano cztery drobne kawałki szkła).

Lokalizacja: $z$ warstwy kulturowej: čtverec Lb 39; inw. č. 602-196/65; ryc. 1: 3 .

Typ chemiczny szkła: sodowo-wapniowo-glinowo-krzemowe $\left(\mathrm{Na}_{2} \mathrm{O} \cdot \mathrm{CaO} \cdot \mathrm{Al}_{2} \mathrm{O}_{3} \cdot \mathrm{SiO}_{2}\right.$; tab. $1: 2 / 41$; tab. $2: 2 / 41$.

3. Nieregularny, amorficzny kawałek zakrzepłej, przejrzystej i błyszczącej ciemnoniebieskiej (granatowej) masy szklanej, barwionej tlenkiem kobaltu $(\mathrm{CoO}->0,1 \%$ ). W szkle widoczne są bardzo liczne, różnej wielkości, na ogół okragłe i nieliczne soczewkowate pęcherze gazowe bez czytelnego układu. Na jednej z powierzchni szkła znajduje się warstwa (gruba ok. $0,3 \mathrm{~cm}$ ) szarej, lekko porowatej szklistej substancji (nie stopiony zestaw szklarski? fryta?). Masa nie została całkowicie wyklarowana (pęcherze gazowe).

Stan zachowania szkła: bardzo dobry.

Wymiary: $0,8 \times 1,0 \times 1,5 \mathrm{~cm}$ (do analizy odłupano kilka drobnych ułamków szkła).

Lokalizacja: $\mathrm{z}$ warstwy ornej; čtverec $\mathrm{Mb} 34$; inv. č. 602-326/65; ryc. 1: 5.

Typ chemiczny szkła: sodowo-wapniowo-glinowo-krzemowe $\left(\mathrm{Na}_{2} \mathrm{O} \cdot \mathrm{CaO} \cdot \mathrm{Al}_{2} \mathrm{O}_{3} \cdot \mathrm{SiO}_{2}\right.$; tab. 1: $3 / 41$; tab. $2: 3 / 41$ ).

4. Nieregularny, amorficzny kawałek zakrzepłej, niejednorodnej, nieprzezroczystej i błyszczącej zielonej masy szklanej, barwionej tlenkiem miedziowym ( $\mathrm{CuO}-2,2 \%$ ). Miejscami widoczne są cienkie pasma ciemniejszego i jaśniejszego szkła. W szkle znajdują się dość liczne, różnej wielkości, na ogół okragłe i pojedyncze soczewkowate pęcherze gazowe bez czytelnego układu. Masa nie została całkowicie wyklarowana (smugi i pęcherze gazowe).

Stan zachowania szkła: bardzo dobry.

Wymiary: 1,0 × 1,5 ×2,2 cm (do analizy odłupano kilka drobnych kawałków szkła).

Lokalizacja: $z$ warstwy kulturowej; čtverec Mb 37; inv. č. 602-543/65; ryc. 1: 1 .

Typ chemiczny szkła: sodowo-wapniowo-ołowiowo-glinowo-krzemowe $\left(\mathrm{Na}_{2} \mathrm{O}\right.$ CaO $\mathrm{PbO} \cdot \mathrm{Al}_{2} \mathrm{O}_{3} \cdot \mathrm{SiO}_{2}$; tab. 1: 4/41; tab. 2: 4/41).

5. Nieregularny, amorficzny kawałek zakrzeplej, jednorodnej, przejrzystej i błyszczącej ciemnoniebieskiej (granatowej) masy szklanej, barwionej tlenkiem kobaltu (CoO $->0,1 \%$ ). W szkle widoczne są bardzo liczne okragłe, drobne pęcherze gazowe bez czytelnego układu. Masa nie została całkowicie wyklarowana (pęcherze gazowe).

Stan zachowania szkła: bardzo dobry. 
Wymiary: $1,8 \times 2,0 \times 2,4 \mathrm{~cm}$ (do analizy odłupano kawałek szkła o średnicy około $1,0 \mathrm{~cm})$.

Lokalizacja: z warstwy kulturowej; čtverec $\mathrm{Nb} 32$; inv. č. 602-675/65; ryc. 1: 4. Typ chemiczny szkła: sodowo-wapniowo-glinowo-krzemowe $\left(\mathrm{Na}_{2} \mathrm{O} \cdot \mathrm{CaO} \cdot \mathrm{Al}_{2} \mathrm{O}_{3} \mathrm{SiO}_{2}\right.$; tab. $1: 5 / 41$; tab. $2: 5 / 41$ ).

\section{ZUR FRAGE DER GLASPRODUKTION IM KELTISCHEN OPPIDUM STARÉ HRADISKO IN MÄHREN}

\section{Zusammenfassung}

Im spätlatènezeitlichen keltischen Oppidium Staré Hradisko wurden mehrere Dutzend Rohglasstücke gefunden, die ein zur weiteren Formgebung vorgesehenes Produkt des Glasschmelzverfahrens darstellen.

Für unsere Untersuchungen wurden fünf Glasstücke ausgewählt (drei dunkelblaue, ein gelbes und ein grünes), die einer spektrographischen Analyse unterzogen wurden und deren Morphologie detailliert beschrieben wurde.

Als Ergebnis dieser Forschung wurden folgende Arbeitsthesen formuliert:

1) in Staré Hradisko während der Spätlatenezeit war eine verarbeitende Glaswerkstatt tätig, in der Glasarmringe und wahrscheinlich auch Glasperlen hergestellt wurden;

2) zu deren Herstellung benötigtes Rohglas wurde von einer unbekannten auswärtigen Glasshütte eingeführt, die ihren Sandbedarf durch die Förderung wahrscheinlich nur einer Sandgrube deckte. Diese letzte Annahme bezeugen auffallend ähnliche Anteile von Aluminiumoxid $\left(\mathrm{Al}_{2} \mathrm{O}_{3}\right)$ in untersuchten Glasstücken mit Ausnahme des dunkelgelben Glasstücks, wo dieser Anteil abweichend ist (Tabelle 1: 1/41);

3 ) in der beschriebenen Glashütte war wahrscheinlich nur die Soda-Kalk-Aluminium-Silizium-Technologie bekannt, für die natürliches Soda, Kalk und aluminiumoxidhaltiger Sand verwendet wurde;

4) zur Färbung des Rohglases wurde der Glasmasse Kobaltoxid ( $\mathrm{CoO}$, blau), Eisenoxid ( $\mathrm{Fe}_{2} \mathrm{O}_{3}$, dunkelgelb) und Kupferoxid (Cuo, grün) beigemischt. Für die Herstellung von undurchsichtigem Glas wurde Bleioxid $(\mathrm{PbO})$ verwendet, das für unsere technologische Klassifikation gleichzeitig die Differenzierungsbasis für Soda-Kalk-Blei-Aluminium-Silizium-Glas darstellt.

Diese Schlüsse stellen eine gute Basis für weitere intensivere technologische Untersuchungen dar und öffnen den Weg für umfassende vergleichende Forschungen zur Frage des keltischen Glases insgesamt.

Ziele dieser Forschungen sind wie folgt zu formulieren:

a) die örtliche Bestimmung der Glashütte, die für Staré Hradisko Rohglas produzierte;

b) die Ermittlung des vollständigen in Staré Hradisko hergestellten Warensortiment;

c) die Klärung der Frage, ob in Staré Hradisko auch eine Glasshütte existierte.

Bevor jedoch diese Forschungen unternommen werden können, wären nötig:

1) eine detaillierte, analytische Durchsicht der gesamten Funde vom Oppidium Staré Hradisko, auch Metall- und Keramikfunde, um möglicherweise Fragmente der Glasherstellungswerkzeuge, der Tiegel und der Glasöfen aufzuspüren.

2) die Analyse der chemischen Zusammensetzung der weiteren Rohglasstücke und auch anderer ausgewählter Glasfunde von Staré Hradisko.

Die auf diesem Weg erzielten Forschungsergebnisse könnten das Gesamtbild der keltischen Glasproduktion beeinflussen. 